\title{
MODEL BASED ASSESSMENT OF THE URANIUM MIGRATION IN THE VADOSE ZONE IN THE VICINITY OF FORMER URANIUM MINES IN SOUTH BULGARIA
}

DOI: http://dx.doi.org/10.18509/GBP.2019.12

UDC: $622.349 .5 .06:[502.51: 504.5(497.2)$

\author{
Sava Kolev \\ Dimitar Antonov \\ Vladimir Hristov \\ Geological Institute, Bulgarian Academy of Sciences, Bulgaria
}

\begin{abstract}
Uranium prospecting and mining were carried out in Bulgaria in the period of 1946-1992, when approximately 48 uranium deposits were discovered and exploited on the country`s territory. In the years of active uranium mining, $18000 \mathrm{~km}$ of boreholes were conducted during the exploration-exploitation works. At the same time, in a number of uranium mining sites, the environment situation was more sustainable before the cessation of this activity. This is due to the fact that no uncontrolled drainage of mine waters has been observed to pollute rivers, groundwater and soils. After cessation of the mining and deactivation of the drainage pumps, at number of mines a rise in the groundwater level had been observed followed by discharge of mine water from the boreholes forming surface ponds with uranium-contaminated water. The present study considers the process of infiltration of uranium through the unsaturated zone beneath 8 of these ponds. For this purpose simulation models were performed using HYDRUS-1D software, estimating the cumulative amount of uranium intruded in the vadose zone and its concentrations in the soil profile at different time periods.
\end{abstract}

Keywords: uranium, HYDRUS-1D, simulation models, vadose zone

\section{INTRODUCTION}

The uranium-mining industry in Bulgaria started operation in 1946 in Buhovo, near the city of Sofia. It was carried out by Soviet-Bulgarian company and from 1956 by the Bulgarian state owned company "Redki Metali", with the complicity of Soviet consultants. Approximately 48 uranium deposits were discovered and exploited [1], all concentrated in the southern and western regions of the country. Initially the ore extraction was performed by underground galleries and since 1979 in-situ leaching by sulfuric acid has been also used [2]. In the years of active uranium mining, $640 \mathrm{~km}$ of adits and $18000 \mathrm{~km}$ of boreholes were conducted during the exploration-exploitation works [3]. The produced uranium was exported to the former USSR, first in the form of ore, and after the release of the enrichment factories in Buhovo and Eleshnitsa, as a concentrate. In return of the export, Bulgaria received nuclear fuel for Kozloduy Nuclear Power Plant. In 1992, uranium mining and milling industry in Bulgaria were closed down by Decree No. 163 of the Council of Ministers of the Republic of Bulgaria, which defined the procedure for development of liquidation plans, their approval and the procedure for funding from the national budget [4]. Although almost no preventive measures were implemented during the whole period of mining for the environmental protection [5], in a number of uranium mining sites, the environment situation was more sustainable before 
the cessation of this activity. This is due to the fact that no uncontrolled drainage of mine waters had been observed as to pollute rivers, groundwater and soils. After cessation of the mining and deactivation of the drainage pumps, a rise in the groundwater level had been observed at number of mines followed by discharging of mine water from adits and boreholes forming surface ponds with uranium-contaminated water (Figure 1). The present study considers the process of infiltration of uranium through the unsaturated zone beneath some of these ponds. For this purpose simulation models were performed using HYDRUS-1D software.

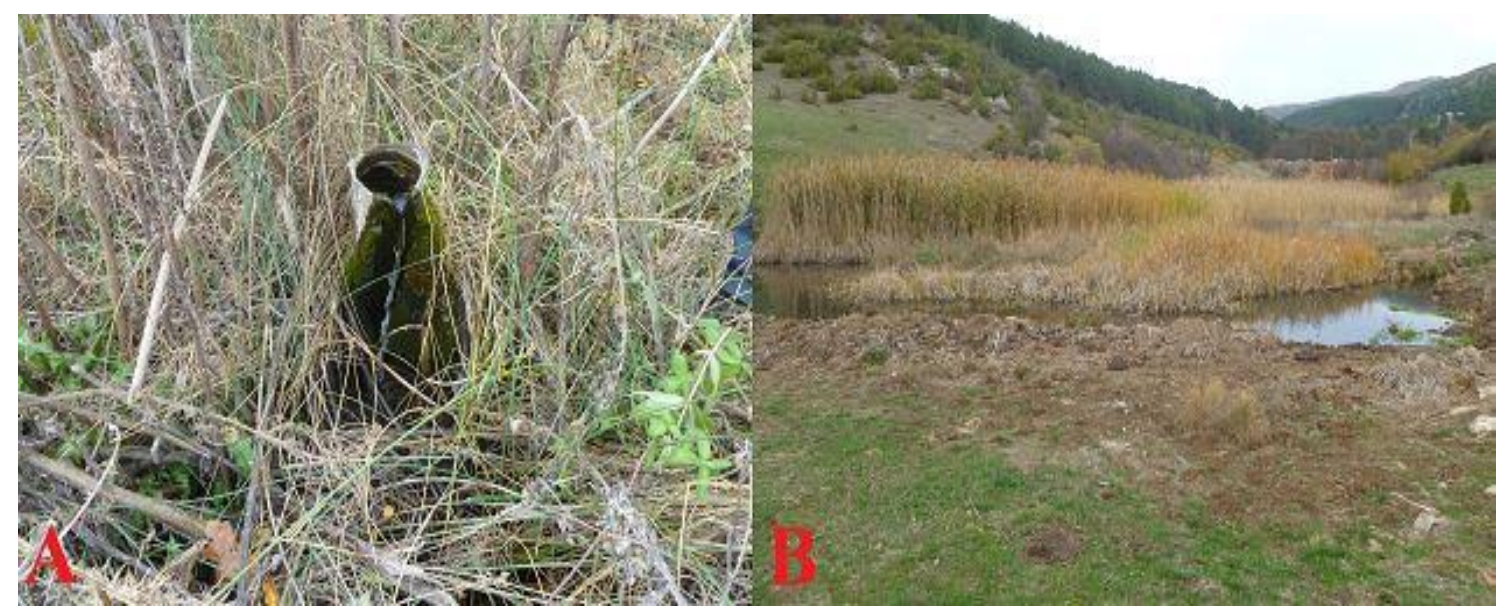

Figure 2. A. Inclined artesian borehole - Gabra uranium mine; B. The pond formed by adit $93-5^{\text {th }}$ shaft uranium mine

\section{METHODS AND MATERIALS}

\section{Study objects}

In order to assess the current ecological impact of the discharged mine water, archive information was reviewed and systematized and 113 adits and boreholes which were reported for presence of leakage were identified. Of these, 40 have been selected, situated on the territory of Southern Bulgaria, on which a field investigation was carried out including on-site measurement of their flow-rates and some physical-chemical variables [6]. Archive information about the contents of uranium in the outflowing water has been provided by the National Center of Radiobiology and Radiation Protection. As a result of the field activities eight surface ponds formed by mine water are selected for the purpose of the present study. They are situated in the range of eight different uranium mines: 5th shaft (Seslavtsi deposit), Gabra, Struma (Simitli deposit), Trilistnik, Debar, Madrets, Vladimirovo, Sborishte (Figure 2).

Physical-chemical variables in the water such as temperature, $\mathrm{pH}$, conductivity and dissolved oxygen were measured in-situ by YSI Professional Plus multiparameter meter. Soil samples for grain-size distribution analyses were taken and analyzed in the laboratory of "Aqua Terra Consult" Ltd. The particle-size data has been used for calculation of the hydraulic parameters of the soil profile. Information about the distribution coefficient $\mathrm{K}_{\mathrm{d}}$ (Table 1) characterizing the soil-solution exchange kinetics which is used to predict radionuclide-soil interaction and subsequent radionuclide transport in the soil [7] was obtained by the National Center of Radiobiology and Radiation Protection [1]. 


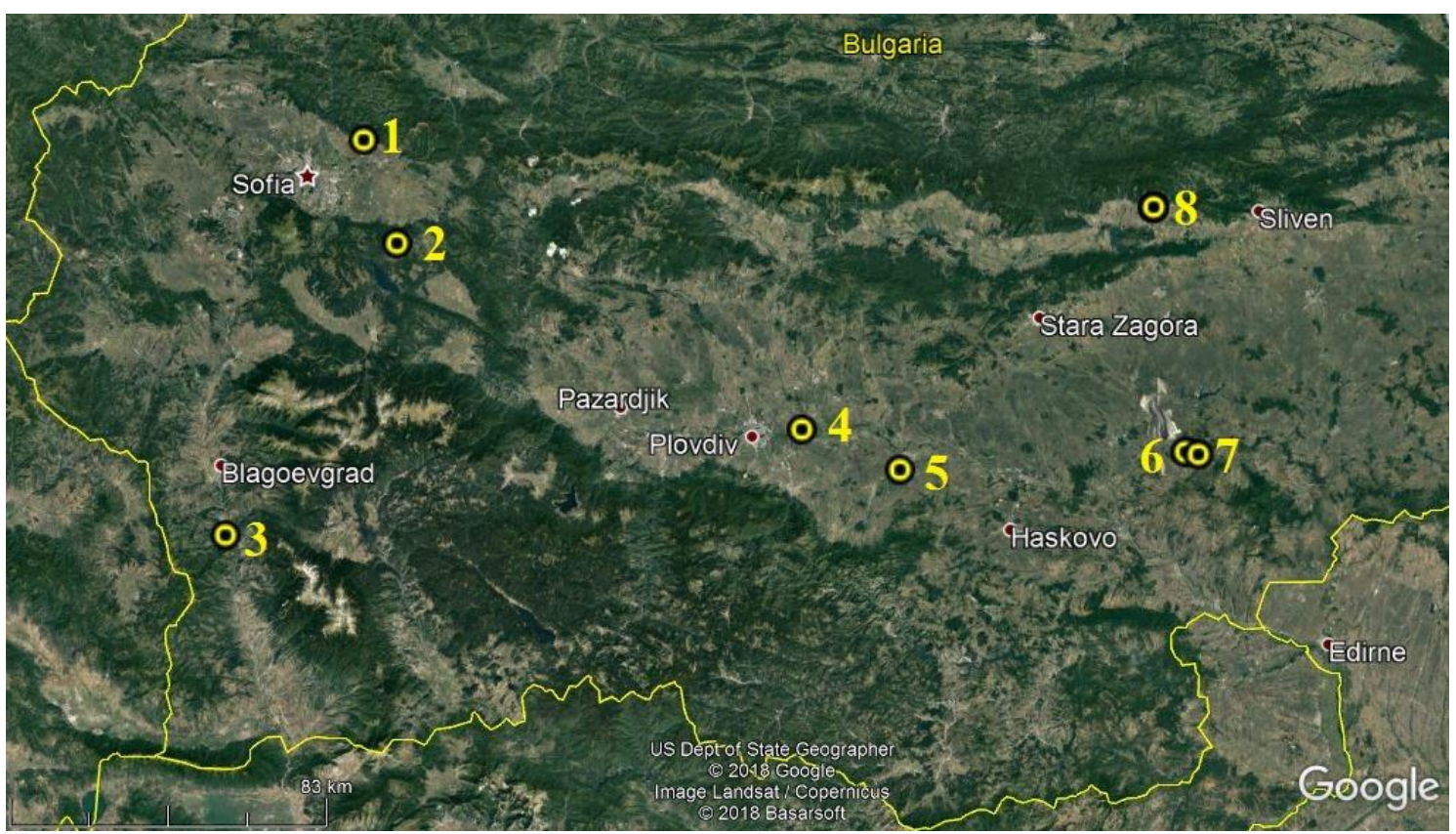

Figure 2. Uranium mines selected for the study (names according to Council of Ministers Decree №74 of 1998 [8]): $1-5^{\text {th }}$ shaft, 2 - Gabra, 3 - Struma, 4 - Trilistnik,

$$
5 \text { - Debar, } 6 \text { - Madrets, } 7 \text { - Vladimirovo, } 8 \text { - Sborishte. }
$$

Table 1. Characteristics of the studied objects

\begin{tabular}{ccccccc}
\hline Uranium mine & $\begin{array}{c}\text { Selected } \\
\text { adit/borehole }\end{array}$ & $\begin{array}{c}\text { Flow- } \\
\text { rate, } \mathbf{1 / s}\end{array}$ & $\begin{array}{c}\text { Pond } \\
\text { area, } \mathbf{m}^{\mathbf{2}}\end{array}$ & $\begin{array}{c}\text { Pond } \\
\text { depth, } \mathbf{m}\end{array}$ & $\begin{array}{c}\text { Uranium } \\
\text { concentration, } \\
\mathbf{m g} / \mathbf{l}\end{array}$ & Kd, 1/kg \\
\hline $\mathbf{5}^{\text {th }}$ shaft & $\begin{array}{c}\text { Adit } 93 \\
\text { Gabra }\end{array}$ & 18.50 & 3486 & 0.50 & 1.309 & 36 \\
\hline $\begin{array}{c}\text { Inclined } \\
\text { artesian } \\
\text { borehole }\end{array}$ & 0.03 & 463 & 0.60 & 0.040 & 98 \\
\hline Struma & $\begin{array}{c}\text { Artesian } \\
\text { borehole }\end{array}$ & $<0.01$ & 106 & 0.10 & 0.005 & 76 \\
\hline Trilistnik & $\begin{array}{c}\text { Artesian } \\
\text { borehole }\end{array}$ & $<0.01$ & 86 & 0.20 & 0.044 & 3255 \\
\hline Debar & $\begin{array}{c}\text { Artesian } \\
\text { borehole }\end{array}$ & $<0.01$ & 629 & 0.20 & 0.088 & 98 \\
\hline Mladrets & $\begin{array}{c}\text { Artesian } \\
\text { borehole }\end{array}$ & 0.01 & 329 & 0.50 & 0.014 & 191 \\
\hline Sborishte & $\begin{array}{c}\text { Artesian } \\
\text { borehole }\end{array}$ & 0.01 & 12482 & 0.50 & 0.061 & 83 \\
\hline
\end{tabular}

\section{HYDRUS-1D CODE}

Simulation vertical profile models were performed using HYDRUS-1D software, estimating the cumulative amount of uranium intruded in the vadose zone and its concentrations in the soil profile at different time periods. The program HYDRUS-1D numerically resolves the advection-dispersion equation on the basis of the solution of the partial differential equation of Richards, which describes the water flow in a variably saturated porous medium [9]. Richards' equation is often comprehensively represented by means of the van Genuchten-Mualem model. Resolving this equation requires the knowledge of two nonlinear functions, namely the soil water retention function and the 
hydraulic conductivity function [10]. Hence, the following so-called hydraulic parameters which describe those characteristic functions need to be known: residual $\left(\theta_{\mathrm{r}}, \mathrm{L}^{3} \mathrm{~L}^{-3}\right)$ and saturated water content $\left(\theta_{\mathrm{s}}, \mathrm{L}^{3} \mathrm{~L}^{-3}\right) ; \alpha\left[\mathrm{L}^{-1}\right]$ and $\mathrm{n}[-]$, which are empirical constants defining the shape of the curves; and saturated hydraulic conductivity $\left(\mathrm{K}_{\mathrm{s}}, \mathrm{L} \mathrm{T}^{-1}\right)$. The hydraulic parameters were determined for each individual soil sample on the base of pedotransfer function analyses using the ROSETTA program incorporated in the HYDRUS-1D.

\section{Modelling schematization}

One vertical profile model was implemented for each of the selected objects. The schematization is in accordance with the field observation data using the information on the soil profiles depth $(100 \mathrm{~cm})$, the archive data, the results from the grain-size distribution analyses and the uranium decay constant. The upper boundary condition was set as specified pressure head (corresponding to the water level of the pond), and the lower boundary condition was set as free drainage. The total time for the simulations was set to 3650 days (10 years).

\section{RESULTS AND DISCUSSION}

The results from the model simulations are presented as uranium concentration in the soil profiles at three different depths (at 25, 50 and $100 \mathrm{~cm}$ ) over time (Figure 3) and as comparison between the cumulative surface and bottom solute flux - the amounts of uranium that intruded the vadose zone and that passed through the bottom of the model profile (at depth of $100 \mathrm{~cm}$ ) (Table 2).

Relatively fast migration of the uranium is observed in most of the objects and within the time of the simulation its concentration in the infiltrating water passing through the bottom of the model profile reaches the concentration value of the surface pond water. The best example is at Gabra where the maximum concentration front reaches the bottom after only 71 days. Quite different is the situation in Trilistnik, where the uranium needs 630 days to reach the depth of $25 \mathrm{~cm}$ and does not reach the next observation depth $(50$ $\mathrm{cm}$ ) within the simulation period. Moreover, after 10 years the uranium concentration at $25 \mathrm{~cm}$ is only $0.003 \mathrm{mg} / \mathrm{l}$ compared to $0.044 \mathrm{mg} / \mathrm{l}$ in the pond.

Comparing the cumulative flux of uranium at the surface and the bottom of the model expressed as retention ratio (Table 2), it is clearly visible that in most of the profiles the major part of the uranium passes through the soil profile freely. It is again the most distinguished case in Trilistnik, where $100 \%$ of the uranium amount entering the vadose zone is retained before reaching the bottom of the profile.

Considering the above presented results it can be concluded that in all objects except Trilistnik the uranium migrates almost unhindered through the upper $1 \mathrm{~m}$ of the unsaturated zone and more detailed simulation is needed with obtaining of soil samples from greater depths - at best to the groundwater level in the area. 

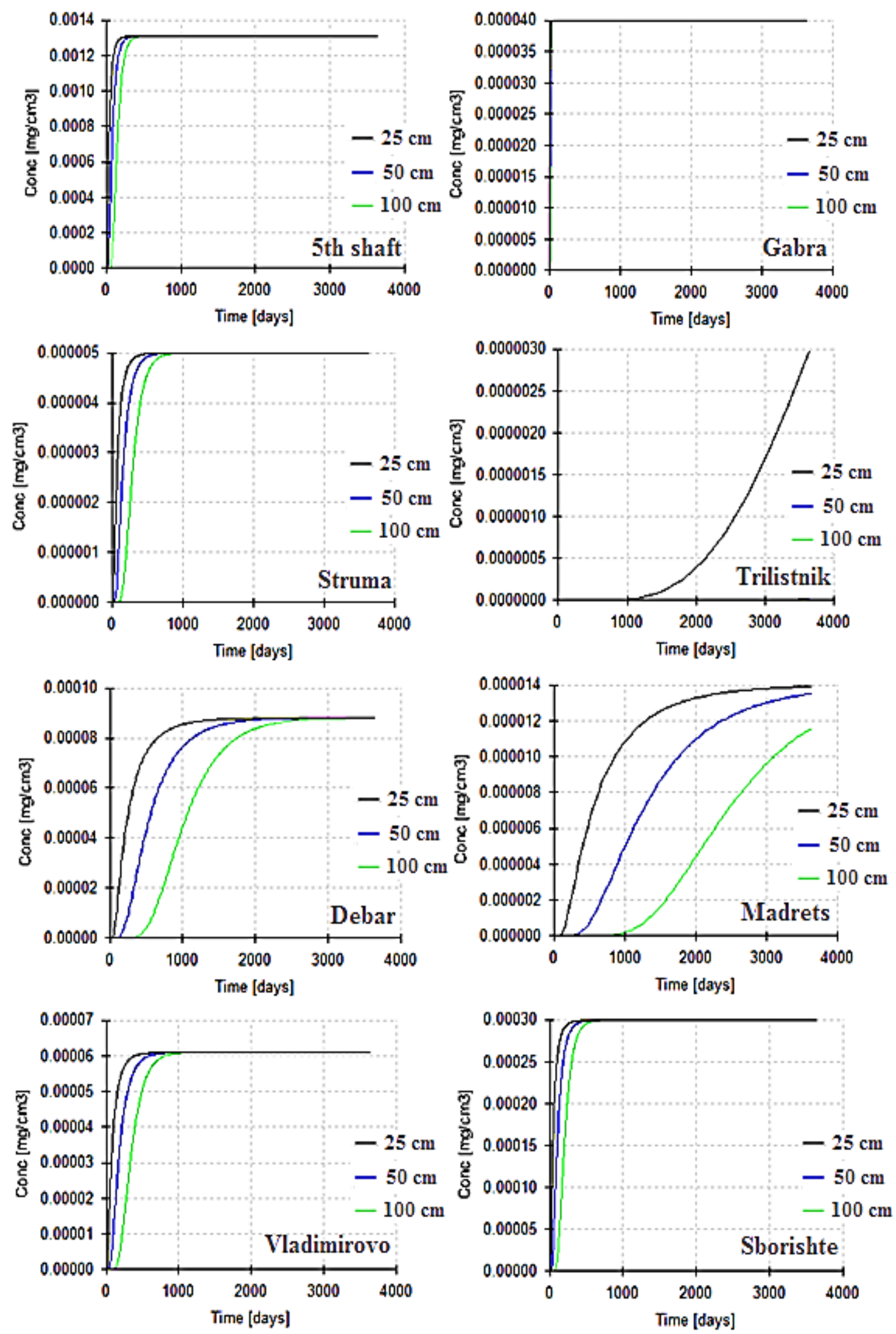

Figure 3. Uranium concentration in the soil profiles (at depths of 25,50 and $100 \mathrm{~cm}$ ) over time 
Table 2. Cumulative surface and bottom uranium flux in the model soil profile

\begin{tabular}{|c|c|c|c|c|}
\hline $\begin{array}{c}\text { Uranium } \\
\text { mine }\end{array}$ & Pond formed by & $\begin{array}{c}\text { Surface uranium } \\
\text { flux, } \mathrm{mg} / \mathrm{cm}^{2}\end{array}$ & $\begin{array}{c}\begin{array}{c}\text { Bottom uranium } \\
\text { flux, } \mathrm{mg} / \mathrm{cm}^{2}\end{array} \\
\end{array}$ & $\begin{array}{c}\text { Retention } \\
\text { ratio, \% }\end{array}$ \\
\hline $5^{\text {th }}$ shaft & Adit 93 & 155.91 & 148.82 & 4.6 \\
\hline Gabra & Inclined artesian borehole & 126.43 & 125.84 & 0.5 \\
\hline Struma & Artesian borehole & 0.62 & 0.56 & 9.2 \\
\hline Trilistnik & Artesian borehole & 1.84 & 0.00 & 100.0 \\
\hline Debar & Artesian borehole & 4.02 & 2.73 & 32.1 \\
\hline Madrets & Artesian borehole & 0.53 & 0.15 & 71.1 \\
\hline Vladimirovo & Artesian borehole & 6.87 & 6.11 & 11.0 \\
\hline Sborishte & Artesian borehole & 528.73 & 493.96 & 6.6 \\
\hline
\end{tabular}

\section{CONCLUSION}

Based on field investigations, archive data and laboratory analyses, eight soil profile numerical models were performed. The total time of the simulation was set at 10 years and from a numerical point of view, all the models had minimal relative errors in the water mass balance of the entire flow domain.

The obtained results showed that at almost all of the studied objects the uranium is migrates almost unhindered through the upper $100 \mathrm{~cm}$ of the unsaturated zone and the maximum concentration front reaches the bottom of the profile within the simulation period. The exception is in Trilistnik where the major part of the uranium amount is retained in the upper $25 \mathrm{~cm}$.

Further investigations with collecting of soil samples from greater depths are needed for performing of more detailed simulations in order to assess more precisely the migration of the uranium in the vadose zone beneath the selected ponds.

\section{ACKNOWLEDGMENTS}

This study was funded by Bulgarian Academy of Sciences in the frames of "Programme for support of young scientists and PhD students in the Bulgarian Academy of Sciences" - Contract DFNP-17-155/02.08.2017.

\section{REFERENCES}

[1] Ivanova, K. 2015. Uranium mining industry in Bulgaria - existing exposure situation and risk for the population. PhD Thesis, Ministry of health, National Center of Radiobiology and Radiation Protection, Radiation control department, 112 p. (in Bulgarian);

[2] Bekman, I. 2009. Uranium. Moscow State University “M.V. Lomonosov", 300 p. (in Russian);

[3] Simov, S. 1989. Uranium Exploration in Bulgaria - a review. IAEA TECDOC-597. Assessment of uranium resources and supply. Proceedings of the technical committee meeting held in Vienna, 29 August - 1 September 1989, pp 41-48;

[4] Nedyalkov, K. 1996. Plans for environmental restoration of uranium mining and milling sites in Bulgaria. Planning for Environmental Restoration of Uranium Mining and Milling Sites in Central and Eastern Europe, Proceedings of a Workshop Held Under the Technical Co-operation Project RER/9/022 on Environmental Restoration in Central and Eastern Europe, Felix, Romania, International Atomic Energy Agency, 4 - 8 November 1997;

[5] Mudd, G. 2000. Acid In Situ Leach Uranium Mining: 2 - Soviet Block and Asia. Tailings \& Mine Waste '00, Fort Collins, CO, USA, January 23-26, pp 527-536; 
[6] Kolev, S., V. Hristov, K. Ivanova, B. Kunovska. 2018. Mine water discharge in the region of former uranium mines in Southern Bulgaria. Review of Bulgarian Geological Society, 79, 3, 2018, pp 143-144 (in Bulgarian);

[7] Vandenhove, H., C. Gil-Garcia, A. Rigol, M. Vidal. 2009. New best estimates for radionuclide solid-liquid distribution coefficients in soils. Part 2: Naturally occurring radionuclides. Journal of Environmental Radioactivity, 100, pp 697-703.

[8] Council of Ministers Decree №74 of 1998 for the elimination of the consequences resulting from uranium production and processing, State Gazette, Issue 39/07.04.1998 (in Bulgarian);

[9] Šimůnek, J., M. Šejna, H. Saito, M. Sakai, M.Th. van Genuchten. 2008. The Hydrus-1D Software Package for Simulating the Movement of Water, Heat, and Multiple Solutes in Variably Saturated Media, Version 4.0. HYDRUS Software Series 3, Department of Environmental Sciences, University of California Riverside, Riverside, California, USA, 315 p.;

[10] van Genuchten, M.Th. 1980. A Closed-Form Equation for Predicting the Hydraulic Conductivity of Unsaturated Soils. Soil Science Society of America Journal, 44, pp 892-898. 